\title{
Governance and strategy of entrepreneurial networks: an introduction
}

\author{
Josef Windsperger • George W. J. Hendrikse • \\ Gerard Cliquet • Thomas Ehrmann
}

\begin{abstract}
This special issue focuses on empirical and theoretical papers that help us to better understand the strategy and governance of entrepreneurial networks, such as franchise chains, alliances, and cooperative networks. The following central themes are covered: (I) Which formal governance mechanisms do entrepreneurial networks use in order to reduce transaction cost/agency cost and to increase strategic value? (II) What is the role of relational governance mechanisms (such as information exchange and social ties) for the performance outcomes in franchise chains and cooperatives? (III) Which alliance strategies do entrepreneurial firms pursue to realize a competitive advantage, and what is the impact of resources and capabilities on performance outcomes of entrepreneurial firms. To address these issues, insights from organizational economics (transaction cost theory, agency theory, signaling theory), strategic management perspectives (resource-based,
\end{abstract}

J. Windsperger $(\bowtie)$

Department of Business Administration, University of Vienna,

Oskar-Morgenstern-Platz 1, 1090 Vienna, Austria

e-mail: josef.windsperger@univie.ac.at

G. W. Hendrikse

Rotterdam School of Management, Erasmus University

Rotterdam, Office T08-56, PO Box 1738, 3000 DR Rotterdam,

The Netherlands

G. Cliquet

Institute of Management of Rennes (IAE), Université de Rennes 1,

11, rue Jean Macé CS 70803, 35708 Rennes, France

T. Ehrmann

Institute of Strategic Management, University of Muenster,

Leonardo-Campus 18, 48149 Muenster, Germany knowledge-based and organizational capabilities theory), entrepreneurship theory and the relational governance view are used.

Keywords Entrepreneurial networks · Franchise networks $\cdot$ Cooperatives $\cdot$ Alliances $\cdot$ Formal governance $\cdot$ Relational governance $\cdot$ Strategies . Organizational capabilities

JEL classification $\mathrm{L} 26 \cdot \mathrm{L} 14 \cdot \mathrm{L} 15 \cdot \mathrm{L} 80 \cdot \mathrm{M} 13 \cdot \mathrm{Q} 13$

Entrepreneurial networks, such as franchise networks, cooperatives, retail chains, and alliances (e. g., Gulati 2007; Baker et al. 2008; Goyal 2015; Snow 2015; Windsperger et al. 2015; Buckley and Prashantham 2016; Koch and Windsperger 2017), are important governance modes that enable entrepreneurial firms to achieve superior performance by collaborating with other firms over a specific range of value chain activities (Miles et al. 2005, 2006). As entrepreneurial firms with weak market and resource positions (Katila et al. 2012), they govern their collaborations by using contractual and equity relations. Entrepreneurial networks enable them to improve their competitive position by exploring and exploiting new knowledge (Alvarez and Barney 2001; Lavie 2006; Hayter 2015). Therefore, these firms use entrepreneurial networks to complement their resources and capabilities in order to realize static and dynamic efficiency advantages.

This special issue focuses on empirical and theoretical papers that help us to better understand the strategy 
and governance of entrepreneurial networks. In particular, the studies address the following themes:

First, which formal governance mechanisms do franchise networks use for transaction cost/agency cost savings and strategic value creation? Formal governance mechanisms refer to the structure of decision and ownership rights and the contract design. Insights from organizational economics (transaction cost theory, agency theory (e.g., Williamson 1991; Lafontaine 1992) and strategic management perspectives (organizational capability theory, e.g., Teece et al. 1997; Helfat et al. 2007) are used to investigate the following themes: antecedents of franchise contract termination, franchising proportion and network failure, and organizational capabilities as determinants of multi-unit franchising.

Second, what is the role of relational governance mechanisms (such as information disclosure, signaling and social ties) for the performance in franchise networks and cooperatives? Applying insights from organizational economics (transaction cost theory, signaling theory, e.g., Gallini and Lutz 1992; Spence 2002) and the relational governance view (e.g., Dyer 1997; Dyer and Singh 1998) the papers focus on the following issues: quality signaling and voluntary information disclosure in franchising and the value of pooling in cooperative entrepreneurial networks (Liang and Hendrikse 2016).

Third, which alliance strategies do entrepreneurial firms (such as franchisee firms and spin-offs) pursue to realize a competitive advantage, and what is the impact of resources and capabilities on performance of entrepreneurial firms?
Research results based on insights from resourcebased, knowledge-based and organizational capabilities theories (e.g., Barney 1991; Teece et al. 1997; Das and Teng 2000; Alvarez and Barney 2001; Lavie 2006; Teece 2014; Scholten et al. 2015) and entrepreneurship theory (e.g., Hébert and Link 1989; Audretsch 2012; Carlsson et al. 2013; Hayter 2015) are used to address the following issues: peer networking strategy and franchisee performance, alliance strategy and innovation performance of spin-off firms, impact of network and managerial capabilities on the performance of entrepreneurial firms, and the role of partner resources in strategic equity alliances for smaller entrepreneurial firm compared to larger firms.

The papers contained in this special issue were first presented at the seventh international conference on Economics and Management of Networks (EMNet) that took place at the Faculty of Economic and Management Sciences (EMS) at the University of the Western Cape from December 3-5, 2015, Cape Town, South Africa. The aim of the conference was to provide an international discussion forum for research in economics and management of entrepreneurial networks.

The special issue is structured in four parts (see Table 1).

\section{Formal governance issues in entrepreneurial networks}

López-Fernández and López-Bayón examine the antecedents of contract terminations in franchising from the franchisor and franchisee perspective. Franchise

Table 1 Overview: governance and strategy of entrepreneurial networks

\begin{tabular}{|c|c|c|}
\hline & Topics & Authors \\
\hline Formal governance issues & $\begin{array}{l}\text { Antecedents of franchise contract termination } \\
\text { Franchising proportion and network failure } \\
\text { Organizational capabilities and multi-unit franchising }\end{array}$ & $\begin{array}{l}\text { López-Fernández and López-Bayón } \\
\text { (2017) } \\
\text { Madanoglu and Castrogiovanni (2017) } \\
\text { Hussain et al. (2017) }\end{array}$ \\
\hline Relational governance issues & $\begin{array}{l}\text { Information disclosure and signaling in franchising } \\
\text { Pooling and social ties in cooperative entrepreneurial } \\
\text { networks }\end{array}$ & $\begin{array}{l}\text { Sadeh and Kacker (2017) } \\
\text { Deng and Hendrikse (2017) }\end{array}$ \\
\hline $\begin{array}{l}\text { Strategy, resources, and } \\
\text { capabilities }\end{array}$ & $\begin{array}{l}\text { Alliance strategy and performance of spin-offs } \\
\text { Peer networking strategy and franchisee performance } \\
\text { Performance effect of network and managerial capabilities } \\
\text { in entrepreneurial firms } \\
\text { Role of partner resources in strategic equity alliances }\end{array}$ & $\begin{array}{l}\text { Hagedoorn et al. (2017) } \\
\text { Brand and Croonen (2017) } \\
\text { Srećković (2017) } \\
\text { Belgraver and Verwaal (2017) }\end{array}$ \\
\hline
\end{tabular}


networks face the challenge of achieving consistency for the entire franchise system while assuring some autonomy for individual franchisees as local entrepreneurs in their ventures. This complex balance constitutes a source of conflict that may lead to termination of the franchise relationship. Franchisors therefore have to decide on the level of empowerment of their franchisees and on different contract provisions to leverage franchisees' capabilities and manage sustainable relationships. Based on data from Spanish franchise chains, this study shows that both parties may have different reactions to the allocation of decision rights. Specifically, the authors focus on pricing and local advertising policies as controversial issues and analyze how decentralizing them is related positively or negatively to contract terminations.

Madanoglu and Castrogiovanni investigate the relationship between franchising proportion of a network and firm failure. Drawing from resource scarcity and agency theories, the authors show that franchising firms that over-franchise and do not structure their networks in congruence with these two theories have lower survival prospects. Firms will franchise to the extent that it offsets resource scarcities and agency costs. As franchising proportion increases to the point warranted by those resource and agency concerns, the likelihood of failure will diminish. However, under an optimal level of franchising for each firm, it is expected that firm failure will increase when the franchising proportion increases beyond the optimum. Madanoglu and Castrogiovanni test the hypothesis with extensive data from nearly 5000 franchising firms listed in Entrepreneur magazine. The main findings suggest that franchising proportion has a U-shape relationship with network failure. Lower levels of franchising proportion are negatively related to firm failure and, at high levels of franchising, firms tend to be more likely to fail. For franchisors, the results highlight the importance of maintaining an appropriate mix of franchised and company-owned outlets within a network.

The franchisor can expand the entrepreneurial network by using single-unit or multi-unit franchising (MUF). Under MUF, a franchisee as local entrepreneur owns two or more outlets in the same franchise chain. Previous research on multi-unit franchising has primarily focused on agency and transaction cost perspectives. Franchisors choose local entrepreneurs as owner of a mini-chain to reduce coordination and monitoring costs. The study of Hussain, Sreckovic and Windsperger complements these organizational economics explanation by developing an organizational capability (OC) model of the franchisor's choice of MUF. According to the OC view, the franchisor can gain a competitive advantage by efficient exploration and exploitation of firm-specific resources and capabilities. The franchise system's exploitation capabilities include knowledge transfer capabilities, human resources management capabilities and monitoring capabilities, and exploration capabilities refer to capabilities regarding the development of new business processes and organizational routines, skills, products, and services. It is hypothesized that, if the franchisor expects to obtain a competitive advantage from higher exploration and exploitation capabilities when using MUF as opposed to single-unit franchising, the franchisor will choose a multi-unit ownership strategy in the franchise system. Based on data from the 167 German and Swiss franchise networks the findings show a positive impact of the franchise system's organizational capabilities (exploration and exploitation capabilities) on the franchisor's choice of the multi-unit ownership strategy.

\section{Relational governance issues in entrepreneurial networks}

When prospective franchisees consider buying franchising rights from a franchisor, they are likely to be interested in knowing how much money an average franchisee can make in that chain. It is possible that franchisee dissatisfaction with unmet expectations can be traced to incomplete information available to prospective franchisees about the quality of the franchisor - this reflects the classical adverse selection problem in agency theory. Since there is no precise way to measure or guarantee future outcomes for new franchisees, franchisors may decide to voluntarily disclose some information about their current outlets' financial performance to signal the quality of their business concept. Sadeh and Kacker examine antecedents of voluntary information disclosures for standardized contracts in entrepreneurial networks using the context of franchising. Entrepreneurs (e.g., franchisors) may make such disclosures to prospective business partners in order to signal profitability of partnering, attract financial and managerial resources, and develop their entrepreneurial networks. The authors draw on signaling theory to develop a theoretical framework and investigate factors that influence a franchisor's disclosure decision. Based on multi-sector panel data for 
the U.S. franchising industry, the results support the view that franchise firms signal their quality through financial performance representations to attract potential business partners and expand their entrepreneurial networks. The study contributes to the entrepreneurship literature by exploring the quality signaling role of voluntary information disclosure in business-to-business context.

Deng and Hendrikse investigate the value of pooling in cooperative entrepreneurial networks. A cooperative is an enterprise owned by a network of entrepreneurial members. For instance in agricultural cooperatives, this entrepreneurial network is formed to advance their member's economic interests by bringing the following benefits: economies of size, elimination of double marginalization, profits from processing, assurance of product outlet, gains from vertical and horizontal coordination, risk reduction, countervailing power, competitive yardstick effect, and auxiliary services for members. Deng and Hendrikse address the question why do cooperatives often pay a pooled price, despite the freeriding incentives it entails? In a pooling arrangement, all network members receive the same price for the delivered quantity of inputs. The local nature of cooperative membership entails that the members as entrepreneurs are likely to know each other and have social ties. By taking explicitly into account the social interactions among entrepreneurial members and the impact of social ties on members' product quality provisions, the authors identify the circumstances when pooling is efficient. It is shown that social interactions mitigate the free-riding effect of pooling and that the amount of members' social interactions depends upon, and increases with, the cooperative's level of pooling. The authors argue that the survival of cooperatives as an entrepreneurial network pursuing a pooling strategy may strongly depend on the intensity of local market interactions related to the exchange of specific knowledge. For instance, if the knowledge exchange is based on explicit contracts and does not require social interactions between the firms, the pooling policy is suboptimal.

\section{Strategy, resources, and capabilities of entrepreneurial firms}

Despite the wide recognition of alliances as major vehicle for knowledge transfer and access to other firms' knowledge-based resources and capabilities, prior research gave limited attention to whether and how formation of alliances affect the performance of spin-offs, as a specific group of entrepreneurial firms. In their study, Hagedoorn, Lokshin, and Malo examine the impact of alliance strategy on the innovation performance of spin-offs firm, differentiating between spin-offs from either other firms or from public research organizations. In particular, the questions are analyzed to what extent alliances of spin-offs with other firms (either large or small and medium sized firms) do affect their innovation performance and how this performance may be affected by their corporate or public research background. Based on data from the combinatorial chemistry industry, the authors find evidence that in general alliances of spinoffs with other firms, in particular alliances with large firms, increased their innovation performance. Corporate spin-offs that formed alliances with other firms outperformed public research spin-offs with such alliances. This suggests that, in terms of their innovation performance, corporate spin-offs that engaged in alliances with other firms seemed to have benefitted from their prior corporate background. It turns out that the negative impact of alliances on the innovation performance of public research spin-offs was largely affected by their alliances with small and medium sized firms. Therefore, the analysis of alliance strategies of spin-offs shows that the consequences of the choice of alliance partner for a spin-off's innovation performance depend on its background (i.e., corporate as opposed to university or public research).

Recent studies have called for a better understanding of the link between networking and entrepreneurial performance. Brand and Croonen combine knowledge and learning perspectives with a networking perspective to develop and test a multi-faceted framework on the effects of franchisee peer networking strategy within a franchise system on franchisee unit performance. In particular, it is argued that the performance benefits that franchisees draw from networking with their peers vary between low, medium, and high performing franchisees. Based on data from a Dutch franchise system, the results confirm that structural, resource and relational facets of franchisee peer networking affect unit performance, and that they benefit and harm low, medium, and high performing franchisees differently. Specifically, the authors show that high performers will benefit from a strong network position and peer operational quality, while they suffer from having network relationships 
with peers with high sales quality and frequent communication. For medium performers, only a strong network position will improve sales performance, and too much communication will come at the cost of decreasing sales. For the low performers, having peer relationships with high sales performers will help to improve franchisee unit performance. Overall, the authors conclude that what may be a blessing for one group of franchisee entrepreneurs is a curse for some others.

Building on the organizational capabilities view, Sreckovic explores the impact of network and managerial capabilities on the performance of entrepreneurial firms in the architecture and real estate sector. The author applies an extended organizational capabilities model by integrating Porter's value chain model and Grant's hierarchy of organizational capabilities model. Starting from differences in entrepreneurial orientation between architecture and real estate development firms the author argues that, in uncertain dynamic environments, network capabilities compared to managerial capabilities are more important for firm performance in architecture firms than in real estate development firms. This may be due to the fact that architects as smaller entrepreneurial firms are much more dependent on reputation and network relationships. They need to initiate and maintain close relationships with their clients in order to acquire new projects and remain competitive in highly uncertain markets. Employing data from Austria, Germany and Switzerland, the research results support the hypotheses. This study contributes to the strategic entrepreneurship literature by showing that network capabilities are more important for creating competitive advantage in entrepreneurial firms than in other firms.

Access to complementary resources through strategic equity alliance networks is an important activity for both smaller entrepreneurial firms and larger firms. The study of Belgraver and Verwaal explores the role of partner resources in strategic equity alliances for smaller entrepreneurial firms and larger firms. In the economics and management literature, it is often assumed that in alliances with larger firms, smaller firms face more challenges in integrating knowledge than their larger counterparts and are more sensitive to hold-up in alliances due to higher specific investments. Specifically, the authors argue that the attributes of partner organizational capital are negative related, and the attributes of partner production factor resources are positive related to the smaller firm financial performance. By applying a longitudinal analysis to a dataset of 1730 firm-year observations of strategic equity alliances in the software industry in 25 countries over an 11-year period, the results show that smaller firms in strategic equity alliances are less able to integrate the organizational capabilities of larger firms, because smaller firms and the organizational and structural properties that come with smaller size may hamper the capacity to absorb the partner's organizational capital. On the other hand, smaller firms benefit more from production factor resources compared to larger partner firms. Overall, the findings indicate that entrepreneurial networks provide important opportunities as well as threats for the smaller entrepreneurial firms.

Acknowledgements Open access funding provided by University of Vienna.

Open Access This article is distributed under the terms of the Creative Commons Attribution 4.0 International License (http:// creativecommons.org/licenses/by/4.0/), which permits unrestricted use, distribution, and reproduction in any medium, provided you give appropriate credit to the original author(s) and the source, provide a link to the Creative Commons license, and indicate if changes were made.

\section{References}

Alvarez, S. A., \& Barney, J. B. (2001). How entrepreneurial firms can benefit from alliances with large partners. Academy of Management Executive, 15, 139-148.

Audretsch, D. (2012). Entrepreneurship research. Management Decision, 50, 755-764.

Baker, G. R., Gibbons, R., \& Murphy, K. J. (2008). Strategic alliances: bridges between islands of conscious power. Journal of Japanese International Economics, 22, 146-163.

Barney, J. B. (1991). Firm resources and sustained competitive advantage. Journal of Management, 11, 791-800.

Belgraver, H., Verwaal, E. (2017). Organizational capital, production factor resources, and relative firm size in strategic equity alliances. Small Business Economics, (this issue).

Brand, M. J., Croonen, E. P. M. (2017). Entrepreneurial networking: a blessing or a curse? Differential effects for low, medium and high performing franchisees. Small Business Economics, (this issue).

Buckley, P. J., \& Prashantam, S. (2016). Global interfirm networks: the division of entrepreneurial labor between MNEs and SMEs. Academy of Management Perspectives, 30, 4058.

Carlsson, B., Braunerhjelm, P., McKeley, M., Olofsson, C., Persson, L., \& Ylinenpää, H. (2013). The evolving domain of entrepreneurship research. Small Business Economics, 41, 913-930.

Das, T. K., \& Teng, B.-S. (2000). A resource-based theory of strategic alliances. Journal of Management, 26, 31-61. 
Deng, W., Hendrikse, G. W. J. (2017). Social interactions and product quality: The value of pooling in cooperative entrepreneurial networks. Small Business Economics, (this issue).

Dyer, J. H. (1997). Effective interfirm collaboration: How firms minimize transaction costs and maximize transaction value. Strategic Management Journal, 18(7), 535-556.

Dyer, J. H., \& Singh, H. (1998). The relational view: cooperative strategy and sources of interorganizational competitive advantage. Academy of Management Review, 23, 660-679.

Gallini, N. T., \& Lutz, N. A. (1992). Dual distribution and royalty fees in franchising. Journal of Law, Economics, \& Organization, 8, 471-501.

Goyal S (2015) Networks in economics: a perspective on the literature Cambridge-INET working paper series no: 2015/05

Gulati, R. (2007). Managing network resources: alliances, affiliations and other relational assets. Oxford: Oxford University Press.

Hagedoorn, J., Lokshin, B., Malo, S. (2017). Alliances and the innovation performance of corporate and public research spin-off firms. Small Business Economics, (this issue).

Hayter, C. S. (2015). Conceptualizing knowledge-based entrepreneurship networks: perspectives from the literature. Small Business Economics, 41, 899-911.

Hébert, R. F., \& Link, A. N. (1989). In search of the meaning of entrepreneurship. Small Business Economics, 1, 39-49.

Helfat, C. E., Finkelstein, S., Mitchell, W., Peteraf, M. A., Singh, H., Teece, D. J., \& Winter, S. G. (2007). Dynamic capabilities: understanding strategic change in organizations. Oxford: Blackwell.

Hussain, D., Srećković, M., Windsperger, J. (2017). An organizational capability perspective on multi-unit franchising: Evidence from Germany and Switzerland. Small Business Economics, (this issue).

Katila, R., Chen, E. L., \& Piezunka, H. (2012). All the right moves: how entrepreurial firms compete effectively. Strategic Entrepreneurship Journal, 6, 116-132.

Koch, T., \& Windsperger, J. (2017). Seeing through the network: competitive advantage in the digital economy. Journal of Organizational Design, 6(6), 2-30.

Lafontaine, F. (1992). Agency theory and franchising: some empirical results. The rand journal of economics, 23, 263-283.

Lavie, D. (2006). The competitive advantage of interconnected firms: An extension of the resource-based view. The Academy of Management Review, 31(3), 638-658.
Liang, Q., \& Hendrikse, G. W. J. (2016). Pooling and the yardstick effect of cooperatives. Agricultural Systems, 143, 97-105.

Lopez-Fernandez, B., Lopez-Bayon, S. (2017). Antecedents of early terminations in franchising: Franchisor versus franchisee cancellations. Small Business Economics, (this issue).

Madanoglu, M., Castrogiovanni, G. (2017). Franchising proportion and network failure. Small Business Economics, (this issue).

Miles, R., Miles, G., \& Snow, C. (2005). Collaborative entrepreneurship: how communities of networked firms use continuous innovation to create economic wealth. Stanford: Stanford University Press.

Miles, R., Miles, G., \& Snow, C. (2006). Collaborative entrepreneurship: a business model for continuous innovation. Organizational Dynamics, 35, 1-11.

Sadeh, F., Kacker, M. (2017). Quality signaling through ex-ante voluntary information disclosure in entrepreneurial networks: Evidence from franchising. Small Business Economics, (this issue).

Scholten, V., Omta, S. W. F., Kemp, R., \& Elfring, T. (2015). Interaction effects of start-up team capabilities and bridging ties on early spin-off growth. Technovation, 45-46, 40-51.

Snow, C. C. (2015). Organizing in the age of competition, cooperation, and collaboration. Journal of Leadership \& Organizational Studies, 22, 433-442.

Spence, M. (2002). Signaling in retrospect and the informational structure of markets. American Economic Review, 92, 434 459.

Srećković, M. (2017). The performance effect of network and managerial capabilities of entrepreneurial firms. Small Business Economics, (this issue).

Teece, D. J. (2014). A dynamic capabilities-based entrepreneurial theory of the multinational enterprise. Journal of International Business Studies, 45(1), 8-37.

Teece, D. J., Pisano, G., \& Shuen, A. (1997). Dynamic capabilities and strategic management. Strategic Management Journal, $18,509-533$.

Williamson, O. E. (1991). Comparative economic organization: the analysis of discrete structural alternatives. Administrative Science Quarterly, 36, 269-296.

Windsperger, J., Cliquet, G., Ehrmann, T., \& Hendrikse, G. W. J. (2015). Interfirm networks: franchising, cooperatives and strategic alliances. Heidelberg: Springer. 